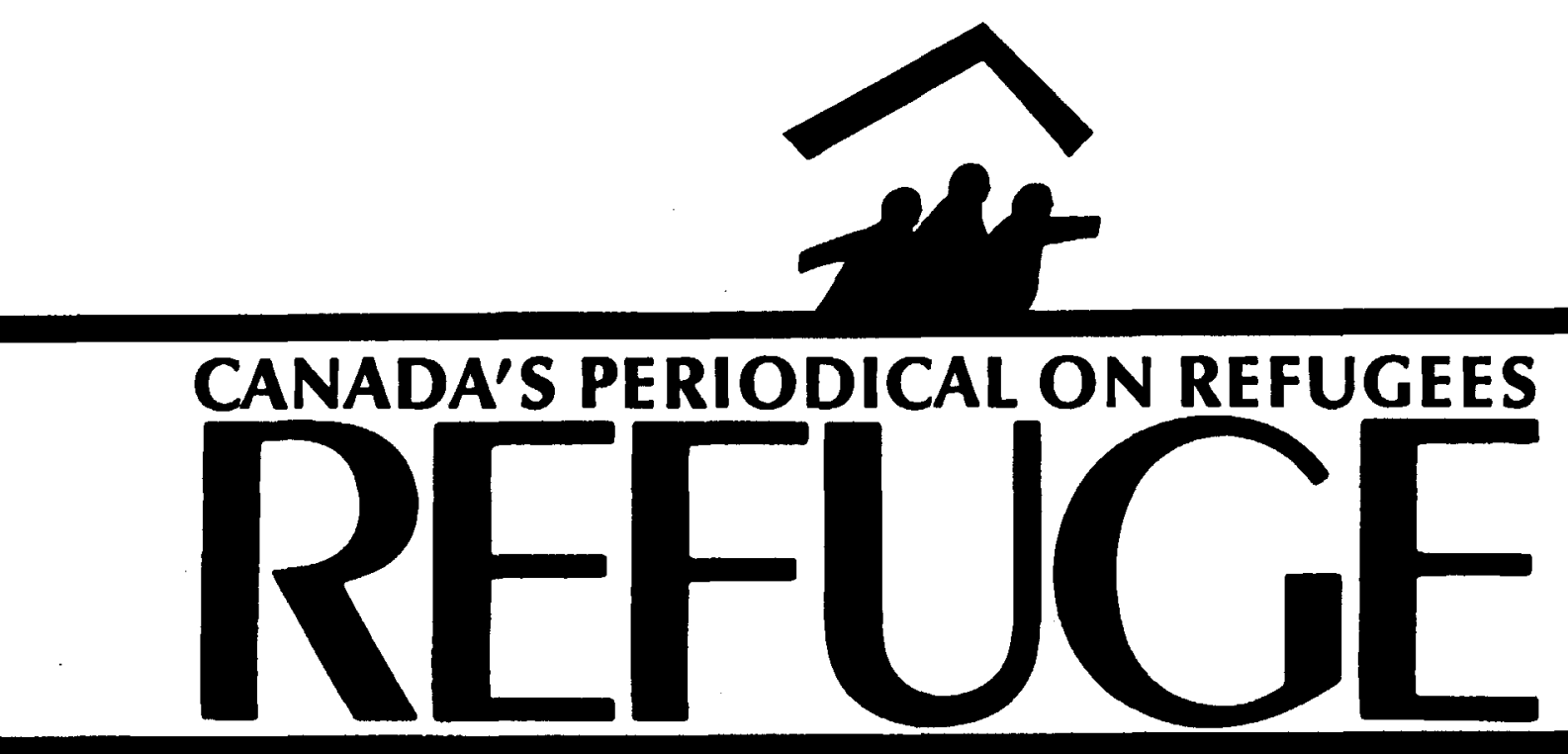

Vol. $12 \cdot$ No. 3

September 1992

\title{
We Can Do More
}

Once again the refugees are fleeing. Once again Canada leaps to the forefront and offers to accept 26,000 of those who have fled the fighting in the former state of Yugoslavia. Headlines scream: "Bosnian Strife Could Kill 500,000"; "Muslims Targeted"; "Red Tape Stalls Bosnian Relief Convoy"; "Horrors of Sarajevo Taking Toll on Canadians;" and, most familiar of all, "The Refugees No One Wants." The fighting has produced over 2,000,000 displaced persons and refugees in the heart of Europe.

Refuge continues to be as relevant as ever as long as human beings treat each other in such atrocious ways. Refuge began with the Indochinese boat people crisis of 1979 and the subsequent private sponsorship movement, so it is relevant that we reexamine the institution of private sponsorship and the proposals for reform. Canada has offered 26,000 places for ex-Yugoslavs. But if there are already over 500,000 refugees outside of Yugoslavia, not counting the estimated over 1,500,000 displaced, why is Canada not offering to take the usual rule-ofthumb figure of 10 percent of the refugee population, or 50,000 ? Why isn't the government again challenging the private sector to sponsor refugees on a one-for-one matching formula? Instead of patting ourselves on the back for doing so much, why are we not kicking ourselves in our butts for doing too little? Even Germany, where xenophobia is rife (as an article in this issue documents), has already received well over 200,000 refugees from the former Yugoslavia, on top of the 500,000 refugees it is already receiving per year.

The fact is we can and should do more, not only for the refugees in Europe but for those in Africa as well. As Ogenga Otunnu suggests, we should be concerned about the refugees there and take proactive initiatives that include a process of resettlement once the refugees arrive in Canada.

This issue of Refuge is a generalissue, yet it has one unifying theme: we can do more and we have the tools to do so.

Howard Adelman, Editor

\section{Contents:}

We Can Do More Howard Adelman ................................................. 1

CEIC Discussion Paper: Private Sponsorship of Program .................. 2

Young Survivors of War and Violent Oppression Susan Beattie ......... 11

An Insurmountable Past? Xenophobia in Germany Today

Ronald Webster ................................................................................... 15

Too Many, Too Long: African Refugee Crisis Revisited

Ogenga Otunnu

Barriers to Educational Pursuits of Refugee Claimants in Canada:

The Case of Ghanaians Edward Opoku-Dapaah .................................. 27

Book Review: Refugees from Revolution:

U.S. Policy and Third-World Migration John Sorenson ..................... 32

Journal Review: Southeast Asian Journal of Social Science,

Vol. 18, No. 1 (1990) Lawrence Lam ................................................. 33

IRB Statistics (January - June 1992) ................................................... 35 